\title{
The Hawaiian Monk Seal
}

\author{
By Dale W. Rice
}

Discovered by seal hunters at the beginning of the nineteenth century, the Hawaiian monk seal was slaughtered with such thoroughness that by the end of the century it was almost extinct. Since then it has slowly built up again to a population of about 1,200 in 1958. This is the total world population. Dale Rice studied the breeding behaviour of this monk seal when working on the albatrosses in Hawaii as a wildlife biologist for the Fish and Wildlife Service. Today he is in charge of whale research at the Marine Mammal Biological Laboratory in Seattle. The article is reproduced by kind permission from "Natural History" journal of the American Museum of Natural History.

$\mathrm{I}^{\mathrm{N}}$ $\mathrm{N}$ the middle of the North Pacific Ocean, the Leeward chain of islands extends like the tail of a comet for 1,200 miles north-west of the main Hawaiian Islands. The islets nearest to Hawaii are jagged chunks of volcanic rock, the remnants of once higher islands. But at the far end of the chain, the volcanic peaks long ago sank beneath the sea ; these islands have kept their heads above water only because their crowns of red corals have grown upward to compensate for the sinking. All summer long an endless succession of heavy ocean swells running before the steady northeast trade winds break over the fringing reefs into sheets of foam, slide over the blue-green shallows and hurl themselves on to the glaring white coral sand beaches. Those lonely beaches and shallow lagoons are the home of one of the world's rarest mammals-the Hawaiian monk seal.

The three species of monk seal are the only tropical and subtropical members of a predominantly cold-water family, the Phocidae, or earless seals. The Mediterranean monk seal Monachus monachus, well known to the ancient Greeks, now survives only in a few scattered colonies in the Mediterranean and Black Seas, and one on the north-west coast of Africa. Columbus discovered the Caribbean monk seal Monachus tropicalis, which was formerly abundant in the Bahamas, the Florida Keys, the Greater Antilles, and along the east coast of Mexico. It probably has been exterminated. The Hawaiian species Monachus schauinslandi is endemic to the Leeward Islands end of the Hawaiian Islands chain.

For many millennia the Hawaiian monk seals lived undisturbed on their remote islands. Apparently even the seafaring Polynesians never reached the western atolls of the Leeward chain, a fact that may account for the seals' survival here-and nowhere else-in the Pacific. In the early 1800 s the intrepid whalers, sealers, feather-hunters, and guanodiggers, who in a few decades filled in the blank spaces on half the globe, discovered the Hawaiian monk seals' retreat. To them, the monk seal was only another source of oil and hides. Their slaughter of the animals on the Leeward Islands was characteristically thorough - almost complete, in fact, by the year 1896, when Dr. H. H. Schauinsland, the German scientist after whom the species was named, visited Laysan Island. 
During his stay he saw no seals, but Max Schlemmer, who operated a guano works on the island, gave him the skull of a seal, one of only seven that had been seen during fifteen years. The Hawaiian monk seal thus barely escaped being exterminated without its existence ever being known to the scientific world.

With the coming of the twentieth century, petroleum reduced the need for whale and seal oil. The age of the seal hunters had ended. The few surviving monk seals and their sea bird neighbours once again were left to themselves. The Commercial Pacific Cable Company, Pan American Airways, and finally the U.S. Navy occupied Midway Island, but they were too busy to bother, or even to notice, the seals. The other five atolls on which the seals lived remained uninhabited and very seldom visited.

\section{Tameness a Characteristic}

When Karl Kenyon and I were assigned to Midway Island in late 1956 to study the albatrosses or "gooney birds ", which nest by the thousands on the Leeward Islands, we were also determined to learn as much as possible about the monk seal-how many there were, and how they lived in an environment so different from that of their cold-water relatives. The first seal I met was sleeping in the shade of the "scavvy" thickets Scaevola frutescens that rimmed the upper edge of the beach. I did not see him until he raised his head to look at me, and then lowered it and shut his eyes. A moment later he raised it again and took another look. With mouth closed he voiced a peculiar " bgg-bgg-bgg-bgg-bgg," like water bubbling from an upside-down jug. He lumbered into the water, dived, and surfaced a few yards off the beach, from whence he continued to watch me a while before swimming off to find a place where he could resume his nap without being interrupted.

This innate tameness, we found, is characteristic of the monk seals-it probably comes from having lived so long on islands where there are no land predators to attack them. Even seals on Midway, which have contended with man for only half a century, are no less tame than those on other, rarely visited islands. When I went spear-fishing, I sometimes saw them watching me under water. These behavioral traits were important clues to the relationships of the monk seal. When I later imitated the bubbling voice for a biologist from New Zealand, he said it sounded just like the leopard seal Hydrurga leptonyx and other Southern Hemisphere species, which share the innate tameness. I have since heard northern elephant seals Mirounga angustirostris utter a similar sound.

\section{The Birth of the Pups}

As spring advanced, and cool, windy days became less frequent, the first pups were born. We found that when the females were ready to give birth to their pups they tended to congregate on certain beaches and islets that were protected from wave action, either by substantial barrier reef, or because they were on the lee side of the island. They were also high enough so that the pup could crawl out of reach of high spring tides. Although mother seals tolerated each other's presence, they vigorously repelled all other seals, particularly courting males that attempted to 


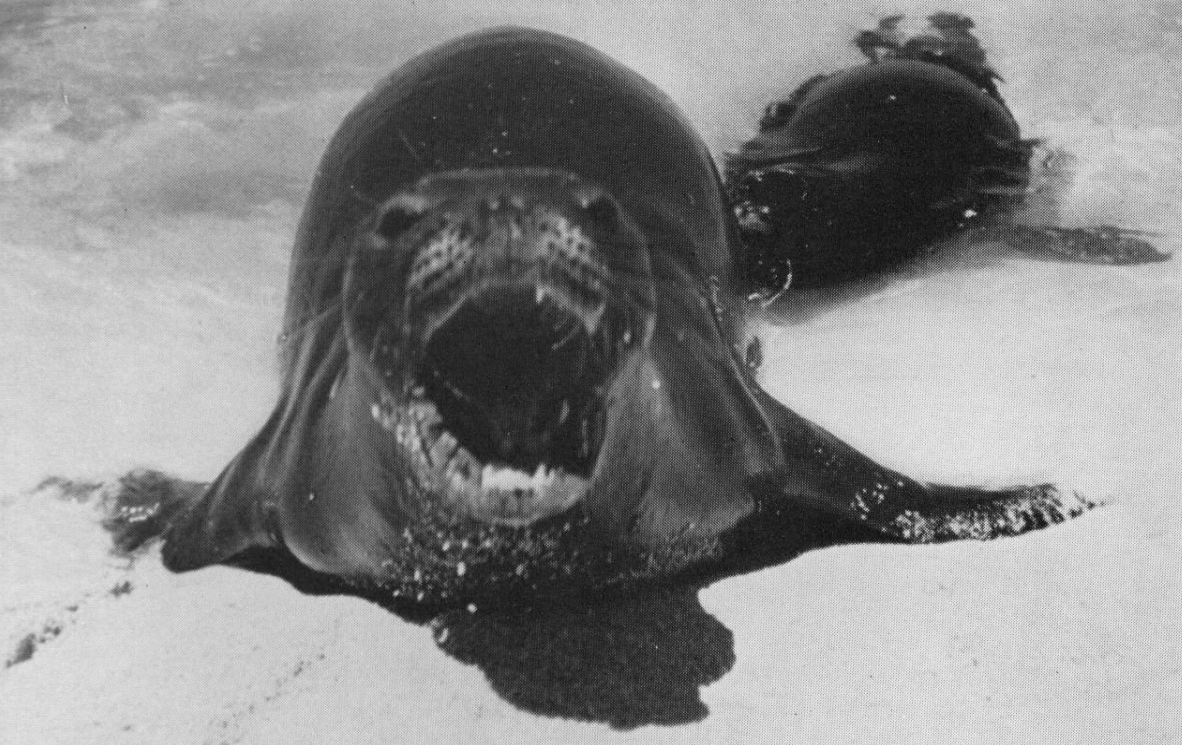

Plate 9 : FURY -A mother seal angrily defends her pup from the photographer.

HAWAIIAN MONK SEALS

Photographs by Dale W. Rice

Plate 10 : BLISS-Monk seals basking on a sand bar at Midway Atoll. 


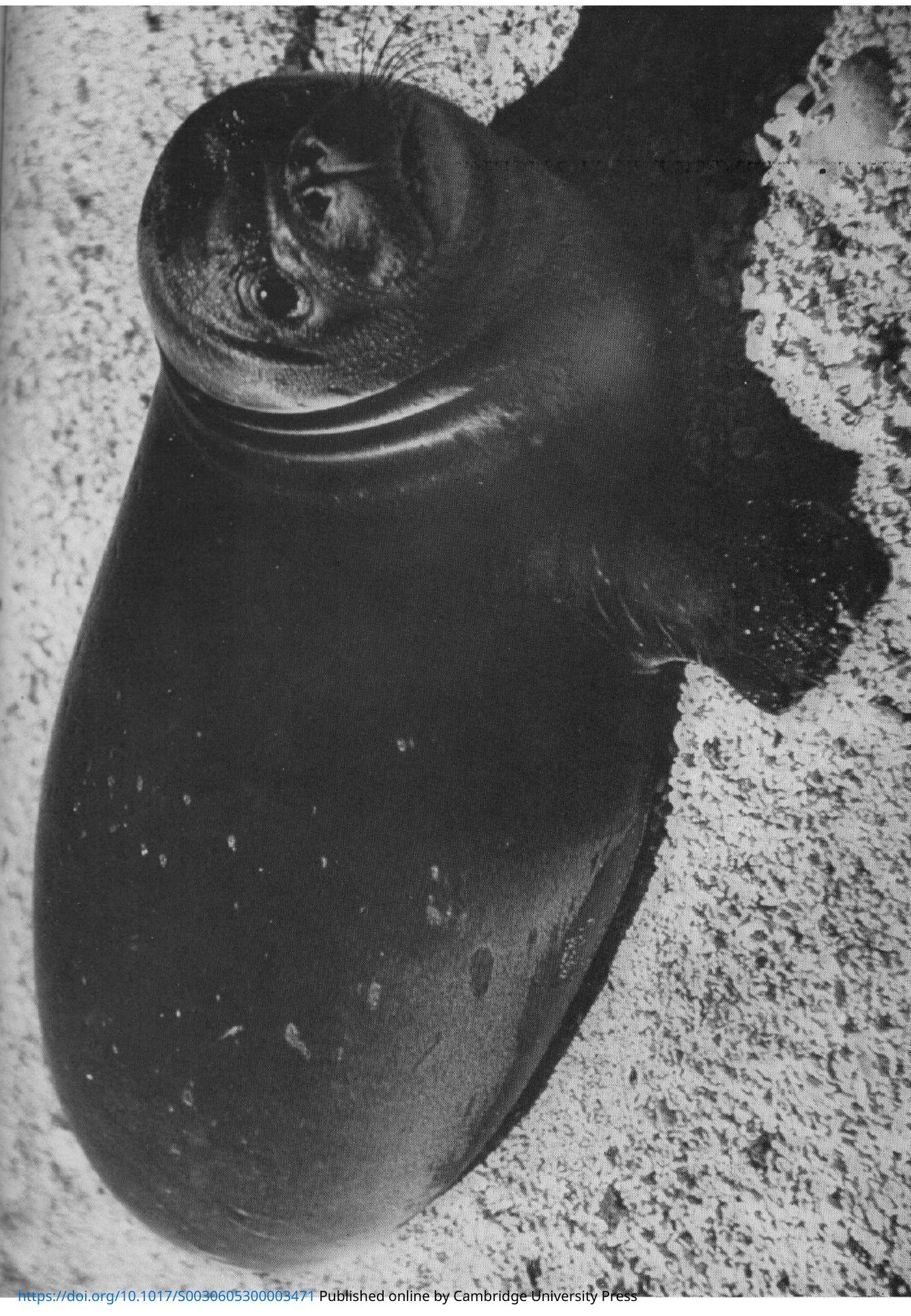




\section{TWO GREAT RARITIES}

The rufous-headed robin, caught 6,660 ft. up a mountain in Malaya and photographed by Dr. H. Elliott McClure, was previously only known from three specimens taken in central China in 1905. The black and white fish Lepidaplois albomaculata, caught by Dr. H. J. A. Wright near Durban, was only known from one specimen and a painting done in Mauritius. Photograph by courtesy of Animals.

See note on page 314. 
approach them. Unlike other species, such as the grey seal Halichoerus grypus and the elephant seal Mirounga leonina, there was no harem formation or other social ties between individual monk seals.

Most of the pups at Midway were born on the small islets that could be visited only by special trips in a small boat. We placed numbered metal tags on the flippers of all these pups, but the weather and our work with the gooney birds prevented us from examining them at regular intervals. Finally one evening in late March a message arrived from Chief Green of the Communications Unit on Eastern Island (a restricted area)-two monk seals had just given birth to pups. The next morning we caught the early boat to Eastern Island. Chief Green led us to the two mother seals, who were lying on the beach beside their tiny, jet-black pups. The mothers were enormously fat. An average non-pregnant female, $7 \mathrm{ft}$. $6 \mathrm{in}$. long, will weigh about 450 pounds, but a pregnant female may weigh 550 to 600 pounds. (Males are smaller; they average about 7 feet in length and 375 pounds in weight.) We were soon to learn the reason for the mother seals' obesity.

The mother seals showed no fear of us. They were not disturbed by our presence until we came too close ; then they threatened us with open mouths and loud bellows. Karl Kenyon had to divert the mothers' attention while I leaped in and kidnapped their pups. We had to weigh, measure, and tag each pup quickly, before its angry mother could get at us. Reunited with their pups, the mothers sprawled on their sides, seemingly oblivious of our presence, and the pups began to nurse. We were surprised to find that the mother monk seal has two pairs of functional teats. All the other species of earless seals, except the bearded seal Erignathus barbatus of the Arctic, have only one pair. The possession of two pairs was probably the condition in the ancestral phocids.

\section{Their First Swim}

We closely followed the development of these two young. At about eighteen days of age, they began to shed their velvety-black birth coat, which is so different from the woolly white or pale-grey birth coats of most cold-water seals. Elephant seals are the only other phocids whose pups are born with black pelage. This dark hair probably protects the species from the intense sunlight of their near-tropical home. The new pelage was short and sparse, and was a dark silvery-grey above, shading to white below, like that of the adults. By the time they were four weeks old, their teeth had begun to appear. This was their permanent set of teeth, for unlike most mammals, the milk teeth of earless seals are resorbed before birth.

At birth the pups weighed less than 40 pounds, and were extremely skinny. With frequent nursing periods, they now began to fill out. By the time they were four days old, they would swim for brief periods in the shallow water. At first they swam weakly, and would sometimes rest their forequarters on their mothers' backs. They soon became strong swimmers and spent more time in the water. The mothers' protective reactions were so strong that, even if they were swimming more than 50 yards offshore with their pups, they would come ashore to threaten us if we appeared 
on the beach. Since their young always followed them ashore, we could catch the pups for periodic weighings. At Kure Atoll, while trying to distract a mother seal so we could examine her pup, I got too close. She grabbed my field notebook from my hands, shook it in her teeth, and flung it down into the sand!

Since the mothers remained with their pups continuously, they had no opportunity to feed, and the frequent nursing of the pups was a heavy drain on their blubber stores. We estimated one mother seal's weight at about 575 pounds when her pup was born. The weights of the pups increased at an unbelievable rate. One of them doubled his birth weight in fifteen days, tripled it in eleven more. By the time he was thirty-five days old, he weighed over 140 pounds, or four times his birth weight. His length had increased from 38 to 49 inches. He was so plump he could hardly move! His mother was now a gaunt creature, for she had lost almost 200 pounds. For each 2 pounds the mother lost, her pup gained one. Eventually, when she no longer could nurse her pup she quietly slipped away and disappeared while he lay sleeping. The other pup, whom we named "Little Herman ", was deserted by his mother when he was but twenty days old, and weighed only 82 pounds. His mother was not as fat as the mother mentioned above and evidently was unable to nurse him any longer.

\section{The Pups Left Alone}

The months ahead were critical ones for the pups, for they had to learn to catch their own food. Their blubber stores helped to tide them through this period. At first they showed little inclination to leave their birthplace. We continued to weigh them at regular intervals. Sometimes we had to wade into hip-deep water to catch them ; then we dragged them ashore, amid tremendous splashing. Their weight steadily fell as they used up their blubber stores, but they were slowly learning the ways of adult seals. We sometimes saw them playing. They would dive, pick up a rock or some other object, bring it to the surface, drop it, and dive again. In this way they probably discovered what things were good to eat. They also began to wander farther from home. When the hot, still days of July arrived, we could no longer find them in their old haunts. They probably moved to the outer reef, where many of the adults haul out during the summer months.

We next saw the pups when the windy days of autumn drove the seals back to the protected islets and sand bars near the main islands. Both their appearance and behaviour were greatly changed. They weighed about a hundred pounds, but they were longer $-4 \mathrm{ft}$. 3 in., on the averageand had the streamlined shape of adult seals. No longer would they docilely let us weigh and measure them. It was a two-man job to wrap them up in a net to immobilise them and keep their strong jaws out of mischief. Although most of the other tagged pups had survived, we never found Little Herman again. Apparently his scant blubber supply failed to last until he learned to find his own food. This is probably how the food supply regulates the number of monk seals. When the seal population is high, supplies of readily available food would be somewhat depleted. 
The females would be unable to put on much blubber, and their pups' chances for survival would be correspondingly reduced. Our observations suggest that female monk seals do not give birth two years in succession. Only the females who do not have pups will accept the advances of the courting males. The physiological strain of rearing a pup probably prevents females from becoming pregnant again until they have regained their store of blubber during at least one entire year of uninterrupted feeding.

\section{Octopuses and Eels for Food}

The only sure way to determine an animals' food habits is to examine its stomach. Because the monk seal is one of the world's rarest mammals, we did not wish to collect many of them. In fact, we killed only twoboth males. We also found the spewed stomach contents of two others. This revealed that they feed principally on octopuses Octopus, moray eels Gymnothorax and Echidna, which live in the crannies among the coral formations, and on conger eels Ariosoma, which burrow in the sandy bottoms of the shallow lagoons. They also take a few bottom fishes and reef fishes, such as flatfish, puffers, and goatfish. Octopuses and eels usually venture out of their hiding places only at night; this suggested that the monk seals feed mostly nocturnally. I had a chance to confirm this during a visit to Laysan Island, where we camped just above the beach. During the middle of the day, we sometimes counted more than 300 monk seals basking in the sun on the beaches. But on several brightly moonlit nights I walked the beaches and found not a single seal except mothers with pups.

In the summer, after the breeding season was over, we discovered another surprising fact about the monk seals. They began to moult their old pelage, now stained a yellowish brown. Instead of shedding each hair individually, like most mammals, they shed the epidermis in large, ragged patches. Shedding the epidermis in this manner is characteristic of reptiles, but of only one other mammal-the elephant seal. This, along with other features, such as the black coat of the pup, suggests that elephant seals and monk seals are closely related.

\section{The World Population}

At Midway, the regular boat run between Sand and Eastern Islands passed near the islets and sand bars that were the seals' favourite hauling grounds. We counted the animals on every trip-sometimes there were more than sixty. Low-altitude photo-reconnaissance flights over the albatross colonies also gave us an excellent opportunity to make periodic counts of the monk seals on Kure Atoll, Pearl and Hermes Reef, Lisianski Island, Laysan Island, and French Frigate Shoals. We also visited some of these islands by ship. The total population in the winter of 1957-58 was about 1,200-a gratifying increase from earlier years, yet a vulnerably low number for any animal species. The reproductive rate of the monk seal is very low, even for a large marine mammal. Females apparently do not breed until they are at least three years old and they probably do not give birth more often than once every two years. The bearded seal is the only other phocid known to have such a breeding cycle. In the spring of 1958, about 170 pups were born, a birth rate of only 14 per cent. 
I saw one seal with a hind flipper missing and others carried large scars on their sides, possibly the result of shark attacks. We encountered many sharks, including 12-foot tiger sharks Galeocerdo cuvieri, in the shallow lagoons, but they seemed to pay no attention to the seals, not even to pups. The seals have no other predators to fear in the shallow lagoons. Our counts indicated that the annual death rate must be very low-about 3 per cent. Like other marine mammals, they tend to live long. Annular layers in the cementum layer of the canine tooth of one adult male that we collected indicated that he was twenty years old. At present the seals seem to be increasing their numbers by approximately 12 per cent each year.

\section{Effects of Human Disturbance}

Except for Midway, which is the site of the large U.S. Naval Station, all the islands on which the monk seals live are part of the Leeward Islands Bird Reservation, administered by the Fish and Wildlife Service, U.S. Department of the Interior. This would seem to ensure their survival. However, in recent years disturbance by man has become an increasing threat. The U.S. Coast Guard has a station on Tern Island in French Frigate Shoal, and has recently taken over Kure Atoll. Seals still occupy Midway, in spite of its large human population, but in 1957 and 1958 at least seven of the eighteen pups born at Midway failed to survive until weaning. On the other islands, we found only one dead pup. The causes of the deaths at Midway apparently were the indirect results of human activity-detonation of explosives in the ship channel, and perhaps persistent disturbance of mothers with pups by photographers, beachcombers, boating parties, and dogs. But on Laysan and Lisianski Islands, and among the vast expanses of Pearl and Hermes Reef, the monk seals still spend the quiet, dark nights fishing in the warm, coral-studded lagoons, and bask undisturbed under the glaring tropical sun, as they have done for uncounted generations. Let us hope that they may continue to thrive and increase for many more.

\section{Conservation Begins at Home}

COUNTRY SIDE, journal of the British Naturalists' Association, recently received this letter from some practical conservationists in Barnsley, Yorkshire :

Dear Sir or Madam,

Could you please send us a free sample of your magazine Countrside. Because when I am older me and some over boys are going to have a magazine called NATURE. If you want a lot of more members I will be able to get you plenty when you send us a magazine. I won't be able to get you lots of members right away but assoon as possible. I route this letter Colin Wright I am the Leader of our gang which is called NATURE GANG. We are excited to see your magazine. Our magazine will tell rules of the countryside and show you all living things of Nature in the British isles it will have 40 pages in it with a picture on every page what we have taken. Us Nature Gang we pick up litter thats left around in the countrside and other things.

Yours truly,

NATURE GANG. 